\title{
Culturas de periferia: entre o mercado, os dispositivos de gestão e o agir político'
}

Livia De Tommasi

\section{Resumo}

O texto apresenta os resultados parciais de uma pesquisa, de caráter exploratório, voltada a indagar as manifestações culturais que acontecem nas periferias de três regiões metropolitanas: Recife, Rio de Janeiro e São Paulo. A percepção de que há, hoje, na sociedade brasileira, um esvaziamento do agir político, no sentido de um agir que explicite uma ruptura com a ordem existente e projete alternativas de mundo possíveis, motivou a busca de outras formas de expressão do conflito. As práticas e atividades culturais periféricas são interrogadas considerando os significados políticos atribuídos pelos sujeitos envolvidos, procurando superar as visões dicotômicas para indagar as ambivalências das práticas entre o mercado da arte e os projetos sociais, a afirmação da identidade territorial e seus limites políticos, a autogestão e o empreendedorismo, a captura pelo discurso que procura sustentar a ideia de "pacificação" das periferias e a afirmação da alteridade, a projeção pessoal e as possibilidades de transformação.

Palavras-chave: Periferia. Política. Movimentos Culturais. Arte Periférica. Produção Cultural.

\section{Introdução}

"ser pobre e ser artista é uma atitude de resistência, é uma luta contra a própria pobreza, claro, é uma porta de inserção social, é uma forma de você se sentir mais seguro, quanto mais popular e sociável você é, principalmente quanto mais próximo você fica de uma sociedade elitista, mais você tem benefícios mesmo sem mudar suas condições econômicas, você vai se sentir mais seguro, tudo porque: ser pobre é um crime"3

I Uma primeira versão desse texto foi apresentada no XXVIII Congresso da Alas, em setembro de 2011.

2 Doutora em Sociologia, professora adjunta do Departamento de Sociologia da Universidade Federal Fluminense (UFF) - Rio de Janeiro - Brasil. Autora, entre outras obras, do liuro Sintonia Jovem: o que pensam e desejam os jovens brasileiros (Cultura Data/Fundação Padre Anchieta, 2008). E-mail: livia.detommasi@gmail.com.

3 Evandro Sena, músico e produtor cultural recifense, entrevista concedida no dia 23/05/20 II. 
Devo às longas conversas com Eleilson Leite, coordenador do programa de cultura da ONG Ação Educativa, grande conhecedor, além de frequentador assíduo, das manifestaçóes culturais da periferia paulista, o interesse por pesquisar o sentido político das atividades artísticas e culturais que acontecem nas periferias ${ }^{4}$.

A percepção de que há, hoje, na sociedade brasileira, um esvaziamento do agir político, no sentido de um agir que explicite uma ruptura com a ordem existente e projete alternativas de mundo possíveis (LAZZARATO, 2004, p. 5-15), motivou-me a ir em busca de outras formas de expressáo do conflito. Como escreveu a socióloga Maria Celia Paoli, que nos anos da democratização pesquisava e escrevia sobre os chamados "novos movimentos sociais", hoje "técnicas de controle e violência operam num mundo esvaziado da política autêntica e de espaços públicos que poderiam acolhê-la" (PAOLI, 2007, p. 225).

Mas não se trata somente de contrapor um presente empobrecido politicamente a um passado supostamente rico em termos de lutas políticas contra-hegemônicas. Minha insatisfação se estendia também às leituras sobre os "novos movimentos sociais" que argumentavam a partir de um único parâmetro explicativo: o de um processo de conquista de uma "democracia ampliada" e de uma "cidadania emergente", através da "luta por direitos" (cf. DAGNINO 1994 e 2004). Categorias analíticas que, a meu ver, acabaram engessando e reificando o que tentavam explicar.

Desde logo, descartei as explicaçóes simplistas e o entusiasmo quase romântico com os quais alguns autores descrevem tudo que acontece de "bom" nas margens geográficas e simbólicas da cidade ${ }^{5}$, procurando, nas minhas leituras, ir além das visóes dicotômicas para indagar as ambivalências, o que acontece "entre": a transgressão e a cooptação, os produtos de mercado e os independentes, as obras originais e as repetiçóes, a arte profissional e o amadorismo. Com a convicçáo de que é justamente nesse "entre" que acontece o que interessa.

Comecei com a periferia de São Paulo, onde estava morando, mas logo minha mudança para o Rio de Janeiro e as conversas com artistas da periferia

4 A pesquisa é financiada com recursos do Conselho Nacional do Desenvolvimento Científico e Tecnológico (CNPq).

5 "Cada vez mais, a periferia toma conta de tudo. Não é mais o centro que inclui a periferia. A periferia agora inclui o centro. E o centro, excluído da festa, se transforma na periferia da periferia." (VIANNA, 2006, p. 12) 
recifense motivaram-me a mudar de perspectiva, a ampliar o zoom e projetar um estudo comparativo, de caráter exploratório, entre as manifestaçóes culturais periféricas de São Paulo, Rio de Janeiro e Recife ${ }^{6}$. Em cada uma dessas cidades tive interlocutores privilegiados que guiaram minhas observaçóes e reflexôes ${ }^{7}$, além de realizar observaçóes durante alguns eventos, debates ou festivais e muitas conversas informais.

Se o interesse é fazer o contraponto com a ideia de esvaziamento da política, primeiramente é necessário aclarar e definir o que chamamos de política. Procurei as referências em alguns autores contemporâneos como Chantal Mouffe e Jacques Rancière, que fazem uma distinção entre a "política", ou seja, as práticas e as instituiçôes que organizam a sociedade, e o "político", cuja característica distintiva é a dimensão do conflito (MOUFFE, 2007; RANCIÈRE, 1996).

Alguns estudos no campo da sociologia da juventude, como os de Helena Abramo (ABRAMO, 2004) para o caso brasileiro, ou Rossana Reguillo (REGUILLO, 2000) para o caso mexicano, há algum tempo mostraram a novidade representada pelos grupos juvenis que se agregam ao redor de algum estilo ou produção cultural. Fugindo das formas tradicionais da política (os partidos, os sindicatos, o movimento estudantil), esses jovens expressariam através do corpo, da performance, da palavra, do traço, suas questôes, demandas, denúncias.

Se o político se distingue pela dimensão do conflito, uma pergunta norteia minhas indagaçóes: que conflitos expressam essas manifestaçóes culturais periféricas ${ }^{8}$ ?

6 Cidade onde morei entre 2002 e 2006 convivendo e trabalhando com jovens artistas e agitadores políticos periféricos.

7 Foram: Eleilson Leite, coordenador de cultura das ONGs Ação Educativa em São Paulo, Dani Francisco, produtora cultural na Baixada Fluminense. Wava Novais, um dos diretores do filme 5xfavelas no Rio de Janeiro, João Lin, desenhista, produtor da revista de quadrinhos Ragú e coordenador assistente da Oi Kabum! Escola de Arte e Teconologia Recife, uma escola de formação em arte para adolescentes das camadas populares financiada pela Oi Futuro no Recife, e Evandro Sena, produtor musical, gestor do Iraq, espaço cultural alternativo, e gerente de cultura na Prefeitura do Recife. Agradeço todos eles pela preciosa colaboração, enquanto tomo para mim a responsabilidade pelas ideias aqui colocadas.

8 Não vou, nesse momento, discutir o conceito de periferia, que merece uma discussão bem maior. Limitar-me-ei somente a fazer algumas anotações sobre seu uso nos contextos estudados. 
O campo da cultura se tornou, nos últimos decênios, um recurso importante tanto para o crescimento econômico (YÚDICE, 2006), como no âmbito das intervençóes de requalificação urbana (ARANTES, 2000). A filósofa Otília Arantes fala, a esse propósito, de um "culturalismo de mercado" (ARANTES, 2000, p. 16). É nesse contexto que podemos situar a visibilidade adquirida pelas manifestaçóes culturais periféricas e compreender os conflitos que as atravessam.

A seguir, descrevo os três cenários-objetos de minhas indagaçóes, traçando distinções e paralelismos entre eles. A multiplicidade e a polifonia das manifestaçôes, as muitas questóes que surgem a partir da observação permitiriam muitos planos de análise. Privilegiei, nesse momento, tentar captar as relaçóes que essas manifestaçóes culturais tecem com seu entorno, geográfico, simbólico e político.

$\mathrm{Na}$ parte final do texto, esboço algumas considerações sobre o entrelaçamento entre as dimensóes econômica, política e artística dessas manifestaçôes, que de nenhuma forma pretendem ser conclusivas, mas abrir pistas que poderão ser seguidas em novos trabalhos de caráter mais analíticos.

\section{Na periferia paulista: entre a afirmação política do pertencimento territorial e o empreendedorismo econômico}

A expressão "culturas de periferia" nasce no contexto da cidade de São Paulo9. Aqui, periferia é um termo cheio de conotaçóes significativas, tanto no âmbito dos estudos acadêmicos como do cotidiano. O estudo das formas de vida dos moradores da periferia, a contraposição periferia-centro, são temas importantes da tradição sociológica paulista. Toda uma geração de sociólogos se formou nessa perspectiva, com base, em particular, nos estudos coordenados por Lucio Kowarick (KOWARICK, 1980 e 1988).

Para Eleilson Leite:

"é por meio da música, literatura, cinema, teatro, dança e de outras linguagens artísticas que o povo pobre dos fundões da metrópole vem dando um novo significado à expressão

9 O documentário Panorama - Arte na Periferia, de Peu Pereira, mostra de forma bastante precisa a cena artística periférica paulista (http://artenaperiferia.blogspot.com). 
periferia. Uma denominação que até os anos 80 designava genericamente o amontoado de precárias residências que ocupam as franjas das grandes cidades. Hoje, a cultura de periferia vem na contra-mão [sic] da história, desmontando os estigmas e os estereótipos que pesam sobre os arrabaldes. Nos becos e vielas do subúrbio pulsa uma arte original, criativa e vibrante. [...] A cultura na periferia surge como elemento aglutinador da comunidade. [...] E a comunidade, diferente do movimento de tipo reivindicatório, se expressa em função do que tem e não por aquilo de que carece. Sendo assim sua manifestação tem um potencial mobilizador de grande intensidade. A cultura gera movimentação social, desperta consciências, embrenha processos políticos, promove transformações. [...] Na periferia, sem arte não há transformação. E para transformar há que se produzir uma cultura própria, porque a "arte que liberta não pode vir da mão que escraviza", como disse o poeta Sérgio Vaz no brilhante manifesto da Semana de Arte Moderna da Periferia, evento emblemático realizado em novembro de 2007 em São Paulo." (E. Leite, Boletim Juventude em Cena, Ação Educativa, 2008).

Além de publicar uma série de artigos na revista Le Monde Diplomatique eletrônica, Eleilson produz, na ONG da qual é um dos diretores, a Agenda Cultural da Periferia, que desde 2007 divulga os eventos culturais que acontecem nas periferias da cidade.

Poetas e escritores como Ferréz, Alessandro Buzo, Sérgio Vaz e os mais jovens Sacolinha e Allan de Rosa, tornaram-se artistas consagrados, que já começam a fazer parte dos programas de estudo escolares e das estantes das bibliotecas municipais. A partir de uma série de três números especiais da revista Caros Amigos dedicados à literatura marginal e organizados por Ferréz, são inúmeros os programas televisivos que hospedaram esses artistas, as matérias publicadas sobre eles e, sobretudo, a circulação de notícias na internet. Ferréz e Alessandro Buzo são também produtores de dois quadros no programa da TV Cultura Manos e Minas que divulgam e discutem as atividades culturais que acontecem nas periferias paulistas.

A Agenda Cultural da Periferia está organizada em cinco sessóes: literatura, Hip Hop, cinema e vídeo, samba, teatro. Há também uma sessão dedicada às manifestaçóes periféricas que acontecem no centro. A literatura ocupa, sem dúvida, um lugar de destaque. ${ }^{10}$ Nesse âmbito, há uma influência importante da cultura Hip Hop. Se a hegemonia musical do Rap perdeu lugar para o

10 Existe já uma vasta literatura acadêmica sobre essas manifestações literárias. Cfr., em particular, o trabalho de Erika Peçanha (2009). 
Funk, mesmos nas periferias de São Paulo, e o grafite é hoje canonizado como linguagem artística "oficial", com espaços dedicados em museus e exposiçóes, a literatura e, sobretudo, a poesia produzida nas periferias paulistas é, em boa parte, um novo produto dos rappers, como se eles tivessem tomado consciência do valor artístico de sua produção literária, ao ponto de fazer dela um produto autônomo em relação à música.

As vicissitudes políticas do movimento Hip Hop no Brasil, as tentativas de organizaçáo em escala nacional, a infiltração de partidos políticos, a cooptaçáo por parte do poder público, a fortuna de alguns artistas e o anonimato de muitos grupos, a "profissionalizaçáo" perseguida por alguns e a "autonomia" reivindicada por outros, mereceriam um estudo específico. Aqui cabe simplesmente lembrar que o Hip Hop que se declina na literatura é fruto também de todo esse processo político. Que tem relação, também, com o que Allan de Rosa nomeou, durante os debates ocorridos no seminário "Estéticas das Periferias: arte e cultura nas bordas da metrópole" ", com a ideia de que o corpo que cria, que produz arte, é também um corpo que precisa se vestir, habitar, comer. Ou seja, com a questão da subsistência individual.

No lugar de esperar que produtores culturais do "centro" valorizassem e colocassem no mercado suas produçôes, os artistas periféricos viraram produtores de si mesmos: produzem e vendem livros, organizam saraus e outros eventos para difundir suas obras. Também criam empreendimentos que produzem riqueza, material e simbólica, para e na periferia: Ferréz criou uma empresa e abriu duas lojas que vendem os produtos de sua grife (a 1DaSul); Allan de Rosa (que fez mestrado em educação na USP) fundou a editora "Ediçóes Toró" e uma ONG para viabilizar a realização de cursos de formação sobre a temática indígena e racial e de criação literária. Sérgio Vaz, Binho e muitos outros animam espaços culturais na periferia e mantêm site ou blog na internet para divulgar suas obras e suas opinióes ${ }^{12}$.

II O seminário foi realizado em São Paulo, em maio de 20 II, fruto da parceria entre a ONG Ação Educativa, - Centro Cultural da Espanha, a Secretaria de Cultura da Prefeitura da Cidade de São Paulo, o Programa Avançado de Cultura Contemporânea da Universidade Federal do Rio de Janeiro (UFRJ) (coordenado pela Professora Heloísa Buarque de Hollanda) e o Núcleo de Antropologia Urbana da Universidade de São Paulo (USP) (coordenador pelo Prof. José Cantor Magnani), com apoio do Serviço Social do Comércio (SESC) e do Ministério da Cultura (MINC).

12 Cfr., dentre muitos, o blog do Sérgio Vaz (www.colecionadordepedras I.blogspot.com) e o do Allan de Rosa ( www.edicoestoro.net). 
Essas iniciativas artísticas e culturais representam também, portanto, um meio de sobrevivência, ainda mais significativo se consideramos que se tratam de grupos sociais subalternos que geralmente têm acesso a postos de trabalho caracterizados pela baixa qualificação, remuneração e gratificação pessoal. Assim, a dimensão econômica dessas iniciativas se entrelaça com a dimensão política.

Essa última é expressa claramente nas palavras de Sérgio Vaz: "O único espaço público que tem na favela é o bar. Você imaginou que a gente ia se acabar tomando cachaça? E a gente transformou os bares em centros culturais"' Colocar um microfone à disposição de qualquer cidadáo que queira fazer seu uso, para ler algum trecho de uma obra própria ou de outros ou declamar um poema, significa legitimar o desejo e o direito à expressão de qualquer cidadão, morador ou náo da periferia, independentemente da qualidade técnica e artística do que é apresentado. Voltarei mais adiante a discutir a questáo do valor artístico reivindicado por essas iniciativas.

O talento empreendedor (e o compromisso político) do Eleilson contribuiu bastante para a difusão dessa produção literária: entre outras atividades, ele convenceu os donos da editora Global a dedicar uma coleção à produção literária periférica. Recentemente, a editora lançou o primeiro livro de um dos artistas mais significativos da cena rap brasileira, o Gog, autor da letra que virou referência importante entre os artistas periféricos: "periferia é periferia em qualquer lugar" (GOG, 2010).

Por sua vez, as rodas de samba, como o Samba da Vela em Santo Amaro, representam uma forma de voltar a valorizar o samba de raiz e escapar, dessa forma, das amarras artísticas, políticas e mercadológicas das escolas de samba. Nesse âmbito é significativa a valorização da cultura negra e indígena brasileira.

$\mathrm{Na}$ área de cinema e vídeo ${ }^{14}$, um impulso significativo tem vindo da grande difusão dos cursos de vídeo organizados no âmbito dos projetos sociais de ONGs e setor público, que parecem ter substituído, nos últimos anos,

13 Sérgio Vaz, no trailer do documentário Curtas saraus (http://artenaperiferia.blogspot.com).

14 A antropóloga Rose Satiko Hijiki está realizando um trabalho analítico importante sobre essa produção. Cf. Hijiki, 2010. 
as propostas de "capacitação" mais tradicionais, com o intuito de "levantar a autoestima", ocupar o tempo livre e potencializar a capacidade de expressão dos jovens ${ }^{15}$.

A influência dos cursos de teatro organizados pelos projetos sociais também tem algum reflexo nas produções da sessão teatro da Agenda Cultural. Mas, nesse âmbito, opera também a herança significativa dos grupos de teatro da cidade, organizados em cooperativa, os primeiros a conquistar um fundo público municipal voltado especificamente a sustentar sua produção.

O compromisso político de Eleilson, formado na escola da Pastoral da Juventude e do Movimento dos Sem Terra, o leva a almejar e trabalhar ativamente para a organização de um movimento cultural da periferia, que articule as atividades e as propostas dos distintos segmentos. Ele mesmo admite, no entanto, a dificuldade dessa empreitada: os diferentes segmentos se assemelham mais a tribos: os integrantes de uma dificilmente se misturam e dialogam com os da outra, ou realizam projetos em conjunto; no momento em que concorrem para os editais e financiamentos, públicos e privados, todos, inevitavelmente, competem pelo acesso a recursos. Mesmo assim, atualmente há várias iniciativas voltadas a articular grupos e coletivos culturais periféricos, como a Rede Livre Leste (na zona Leste da cidade) e a Agência Solano Trindade na zona sul.

Outro fator que contribuiu para produzir a efervescência cultural da periferia paulista é a existência do VAI, o Programa de Valorização das Iniciativas Culturais, um fundo de apoio instituído por uma lei municipal (de autoria do entâo vereador Nabil Bounduki). Tendo sido instituído durante o governo petista de Marta Suplicy, o fundo náo cessou de se ampliar durante os governos sucessivos (de Serra e Kassab). Mesmo assim, é importante salientar que os projetos que o VAI financia nas periferias são em número muito reduzido, em comparação com os financiados nas regiōes ricas da cidade.

O reconhecimento que os artistas periféricos ganharam na mídia, a frequentação por parte de pessoas de classe média dos espaços culturais periféricos são tão significativos que essas manifestações tornaram-se uma referência

15 Em outro lugar, analiso as limitações e a lógica gestionária que anima esse tipo de intervenção, especificamente no campo dos programas dirigidos aos jovens (cf. TOMMASI, 2005, 2007 e 20I2). 
para as produçóes de outras cidades e em particular do Rio de Janeiro, onde começou a se falar também de "periferia" e a se organizar saraus ao estilo do Sarau da Cooperifa, realizado por Sérgio Vaz no Capão Redondo, na periferia sul da cidade de São Paulo.

"Ser" e "estar" na periferia é argumento sempre colocado para legitimar a fala. Expressóes como "nasci e cresci na comunidade tal", proferidas no começo de uma fala pública, colocam naturalmente um divisor de águas entre os presentes. Como disse Allan de Rosa no seminário supracitado: "Cep é vivência". Dessa forma, esses artistas se contrapóem a toda uma herança histórica de desapropriaçáo da fala, a quem continua a falar "em nome de" mesmo ocupando um outro lugar social e geográfico. As falas que, no seminário, colocavam a ideia de superaçáo e de fronteiras borradas entre centro e periferia, alguns participantes (especificamente entre o público) responderam convidando os presentes a ir pegar um ônibus lotado, pela manhã cedo, para constatar que ainda há, e bem evidente, segregação e desigualdades nas condiçóes de vida dos moradores da cidade. "A gente não reside, resiste", disse o GOG no seminário.

Já que o produto traz em si as marcas fortes da identidade territorial, reivindicada e positivada por essa produção, a venda do produto implica valorizaçáo do lugar: a periferia é hoje valorizada como lugar onde se produz cultura, e não somente violência e marginalidade. Há, inclusive, um numero significativo de produtores culturais e jornalistas egressos das escolas da elite (como a Getúlio Vargas) dispostos a investir na difusão dessas manifestações (cf. os vários sites dedicados a essa produção, como o "DoLadoDeCá" da jornalista Tati Ivanovici - www.doladodeca.com.br)

Nesse contexto, cabe a pergunta: o que fica, na periferia, da visibilidade adquirida por essas "culturas de periferia"? Os moradores da periferia, de forma geral, se apropriam do valor adquirido por essas manifestaçôes? Se considerarmos a precariedade das condiçóes de vida, trabalho e moradia nas periferias, a falta de serviços básicos, como saúde, educação, saneamento, transporte, o fato de que os jovens moradores dessas regióes da cidade sofrem quotidianamente com a repressão e a violência policial, não parece que essa valorização das manifestaçóes artísticas e culturais reverbere sobre as outras dimensóes da cidadania. Aliás, o recente fechamento do bar onde acontecia o Sarau do Binho, um dos saraus mais antigos e mais politizados da cidade, demonstra 
que mesmo as iniciativas culturais não estão isentas da repressão. Podemos dizer, com Otilia Arantes, que as atividades culturais que visam estimular a criatividade e aumentar a autoestima operam uma "sensação de cidadania" (Arantes, 2000, p. 47).

Por outro lado, observando o público que frequenta os espaços dos saraus, das rodas de samba e das outras manifestaçóes culturais periféricas, podemos questionar que enquanto o público representado pelos moradores das regióes ricas da cidade náo tem parado de aumentar, o público morador das periferias diminui ou, pelo menos, estagna. Mas infelizmente, entre os muitos estudos que estáo sendo desenvolvidos sobre essas manifestações, nenhum até agora realizou uma análise detalhada do público frequentador e consumidor. Em todo caso, a questão da formação do público é uma questão sempre presente nos debates.

\section{Arte e cultura como dispositivos de gestão das populações nas favelas cariocas}

No Rio de Janeiro é ainda mais evidente a proliferação de cursos, cursinhos e oficinas que se utilizam de alguma linguagem artística para promover o chamado "protagonismo" juvenil, a "elevação da autoestima" e a "conquista da cidadania". Algumas ONGs, como Grupo Cultural AfroReggae e a CUFA (Central Única das Favelas, criada pelo raper MV Bill), adquiriram uma grande visibilidade, que inclusive transbordou as fronteiras nacionais, propondo uma receita para "solucionar" o problema do grande contingente de jovens e adolescentes envolvidos com o "tráfico", através do engajamento deles em atividades artístico-culturais. Essa proposta, nos últimos anos, encontrou uma alta receptividade: hoje a CUFA está presente em todos os estados brasileiros e em 10 países no exterior. O sucesso dessa organização contrasta significativamente com a crise geral que atingiu o mundo das ONGs, sobretudo aquelas mais antigas e formadas no contexto da redemocratizaçáo (especificamente, as ONGs ligadas à Associação Brasileira de ONGs). Enquanto estas últimas estáo fechando as portas ou sobrevivendo à custa de um considerável redirecionamento de suas atividades, formas de organização e objetivos políticos, as ONGs cariocas de "base comunitária" (ou seja, baseadas nas "comunidades", forma "positiva" de chamar as favelas) e que propóem soluçóes ao problema da violência (como o Viva Rio, o Grupo Cultural AfroReggae, a CUFA, Nós do Morro) proliferam. 
Sintomático, nesse sentido, é a organização do evento chamado "O Antídoto - Seminário Internacional de Açóes Culturais em Zonas de Conflito”, organizado pelo Instituto Itaú Cultural em parceria com a ONG AfroReggae, que "aborda a força da arte e da cultura no combate à violência, seja em zonas devastadas pela guerra, seja em conflitos urbanos ou rurais" (cf. Folder da $5^{\mathrm{a}}$ edição do evento). Esse uso da cultura para solucionar problemas sociais não é uma invenção brasileira. George Yúdice comenta justamente sobre o uso utilitarista da arte e da cultura nos Estados Unidos: "melhorar a educação, abrandar a rixa racial, ajudar a reverter a deterioraçáo urbana através do turismo cultural, criar empregos, diminuir a criminalidade [...] os artistas estão sendo levados a gerenciar o social" (YÚDICE, 2006, p. 29). No Rio, a quantidade de cursos de vídeo promovidos pelos programas sociais criou um nicho específico de produção: o nicho dos "egressos", que conquistaram espaços dedicados à exibição de suas produçóes nos festivais de audiovisual, tentaram se organizar num Fórum (o FEPA - Fórum de Experiências Populares em Audiovisual) e disputar uma cadeira no Conselho Consultivo da Secretária de Audiovisual do MINC. O sucesso do filme 5xfavelas idealizado pelo diretor Cacá Diegues com a participaçáo de jovens egressos dos cursos de cinco ONGs cariocas é, nesse sentido, emblemático ${ }^{16}$.

Paralelo a isso, há um interesse crescente do mercado da arte pelo produto "favela" ou "periferia", termos que estão sendo usados, nesse âmbito, como sinônimos. A produção do quadro "Central da Periferia" no programa Fantástico da Rede Globo, em 2006, por Regina Casé e o antropólogo Hermano Vianna; a organização da exposição "Estética da Periferia - inclusão cultural e cidadania" em 2005 pelo produtor Gringo Cardia e a escritora e professora Heloisa Buarque de Holanda; a realização do Festival Visóes Periféricas - Audiovisual, Educação e Tecnologia (que em 2012 realizou a $6^{a}$ edição); a recente organização da exposiçáo "O Design da Favela" no Centro Carioca de Design na Praça Tiradentes, são exemplos significativos desse interesse. As falas de Gringo Cardia no seminário de São Paulo não deixaram dúvida sobre o valor mercadológico dessa operação: "Tira uma peça do camelódromo, tira pela excelência, coloca aquilo isolado numa sala e você passa a ver o que, de

16 Depois do $5 x$ favelas os mesmos diretores filmaram 5xUPP, com o objetivo de mostrar a relação entre moradores e policiais nos chamados "territórios pacificados" onde foram instaladas as Unidades de Polícia Pacificadora. 
outra forma, ficaria invisível." Ele deu vários exemplos, como o do espetáculo "As cidades" de Chico Buarque, onde ele colocou a imagem dos "gatos" elétricos das favelas para adornar (imagem que inclusive está na capa do disco), tornando os "gatos", dessa forma, para ele, "arte contemporânea". Ou seja, tirar um produto do seu meio, torná-lo um produto estético, pinçar um artista do seu contexto e projetá-lo na cena nacional é o papel dos "curadores".

Se essa operação começou já há alguns anos, é somente nos últimos tempos, depois da instalação das Unidades de Polícia Pacificadora (UPP) nas favelas cariocas (programa iniciado em 2008), que ela tomou vulto e significado político. Depois da suposta "pacificação" das favelas, a ênfase na capacidade criativa das populaçóes faveladas (que sempre acompanhou, no Rio de Janeiro, práticas e discursos discriminadores e a produção do estigma sobre os favelados) ganhou novos alentos. "Favela é potência" repete com insistência o produtor cultural Marco Faustini, criador da "Agência de Redes para a Juventude", um programa social que estimula jovens das "comunidades pacificadas" a realizar empreendimentos socioculturais (VELAZCO, 2012). Mais um exemplo da instrumentalização da cultura para resolver problemas sociais.

O teor e a quantidade das informaçóes que circulam na mídia, e em particular na mídia eletrônica, não deixam dúvida: no Rio foi inventado um produto, a favela pacificada, lugar de criatividade, inovação, produção artísticas das "pessoas do bem", para se contrapor à imagem de perigo, violência e marginalidade que durante muito tempo foi divulgada na mídia. Projetos, programas, empreendimentos turísticos visam vender "o encanto das favelas" (nome de um concurso de fotografia organizado pela ONG Viva Rio, no âmbito do programa "Viva Favela").

Paralelo a isso, há iniciativas mais antigas, como o movimento cineclubista, os grupos de rock independentes da baixada fluminense e os anarco-punk das ocupaçóes. Há uma miríade de grupos e indivíduos que fazem arte, música, poesia, teatro, vídeo, promovem iniciativas de forma independente, dentro e fora das favelas. Alguns mais, outros menos, tentam dialogar com o poder público, procurando encontrar algum financiamento. Hoje tanto o Ministério da Cultura como as secretarias estaduais e municipais de cultura ampliaram bastante a oferta de editais. Mas, como lembram meus interlocutores, os editais, com suas regras, colocam um filtro: para concorrer é preciso saber que existem e é preciso estar preparado, regularizado, dominar as técnicas, os códigos e as regras de conduta. 
Se a difusão da mídia digital permitiu a democratização da difusão e produção artística, produzir, divulgar, requer tempo e talento. Como resumiu Mano Brown num debate organizado pelo projeto "Apalpe - A palavra da periferia" e o Fórum de Ciência e Cultura da Universidade Federal do Rio de Janeiro: "hoje todo mundo tem que virar empreendedor de si mesmo" ${ }^{17}$. Ser artista é ser empreendedor. Nesse sentido, iniciativas como a da produtora "Terreiros de ideias" criada por Dani Francisco em Duque de Caxias, que visa conquistar um nicho de marcado para os artistas, tradicionalmente marginais, da Baixada Fluminense, são bastante significativas.

Para quem abraça o discurso do "social" e defende a ideia de que através da arte e da cultura é possível "sair da marginalidade" e promover a "inclusão social", as possibilidades e os circuitos dos financiamentos se ampliam. Mas alguns, como fez Marta Porto, então Secretária de Cidadania e Diversidade Cultural do Ministério da Cultura, durante o seminário supracitado, questionam o valor artístico do que é produzido com finalidades sociais. A arte, para eles, tem que conservar um padrão de qualidade, ou melhor, é o valor artístico que deve motivar os financiamentos e não seu valor social. Mas o que seria essa qualidade, esse valor artístico? Quem (e como) está autorizado a definir o que é arte?

\section{O cenário recifense: entre a busca pelo reconhecimento e a crítica ao padrão estético dominante}

Se as chamadas "culturas de periferia" estão sendo valorizadas, no Rio de Janeiro, como parte da produção de um novo regime discursivo que visa promover o "encontro" da favela com o asfalto, a suposta superação da "cidade partida”, como insistem em dizer os gestores do programa UPP Social (que iniciou no governo estadual e agora é sediado no Instituto Pereira Passos da Prefeitura da cidade), o mesmo não acontece em Recife, onde as periferias não parecem ser objeto de uma requalificação discursiva. O centro é, ainda, por excelência, o lugar do suposto "encontro", numa cidade onde a "participação" e a promoção de eventos artísticos de graça na praça do "marco zero" são, há muito tempo, marcas significativas da gestão pública. Mesmo se, em Recife como nas outras cidades, as possibilidades de circulação são muito limitadas para os que vivem nas bordas (e especificamente para os jovens) da metrópole.

17 Debate gravado, no dia 07/10/2010. 
O cenário recifense serve, de certa forma, para fazer o contraponto com os dois precedentes. A efervescência cultural, e em particular musical, de Recife é suficientemente conhecida. E não somente em época de carnaval. $\mathrm{O}$ Movimento Mangue Beat, que deu notoriedade a Chico Science e Nação Zumbi, Fred O4 e Mundo Livre S.A., é só a ponta do iceberg de uma grande quantidade de grupos musicais. Os ritmos ligados à cultura popular, maracatu, frevo, coco, caboclinho, são muito presentes na vida da cidade e especificamente nos bairros populares. Brasília Teimosa, Alto Zé do Pinho, Peixinhos em Olinda, são bairros periféricos onde existe uma cena musical e artística local significativa.

Se o surgimento do movimento mangue provocou uma forte reação pelo seu "hibridismo" (a mistura de ritmos populares, rock e rap), por parte do crítico Ariano Suassuna, hoje esse mesmo hibridismo é consagrado como uma marca valorizada da música e da arte local.

Mas a visibilidade adquirida por alguns artistas e bandas musicais locais náo deve fazer-nos perder de vista o fato de que o sucesso de alguns (poucos) não reverbera sobre os muitos outros que, ao invés, continuam na invisibilidade e mergulham na falta de apoios financeiros. Falta de apoio e visibilidade que atingem em particular grupos e manifestaçóes da cultura popular. As polêmicas recentes suscitadas pela nova gestáo do programa "Pontos de Cultura" do MINC, em escala nacional, trazem à tona o fato de que, mesmo sendo recursos muito limitados e precários (orientados pela lógica do sevirismo ou "a arte de se virar", como mostrou Gustavo Gannam - Gannam, 2008), é a primeira vez que a maioria das iniciativas de cultura popular consegue acessar algum recurso público.

Se a interlocução com o poder público existe em qualquer contexto brasileiro, no Recife essa é uma característica forte da política local, desde sempre preocupada em fazer da "participação" uma marca da gestão. Durante as últimas gestóes petistas esse diálogo se intensificou, assim como cresceu o número de artistas e produtores da cena independente que assumiram cargos públicos. Na trajetória profissional de qualquer pessoa que se destaque do seu meio é sempre presente a perspectiva de trabalhar no governo.

Há alguns anos, os artistas periféricos locais tentaram se articular, projetando encontros e iniciativas em conjunto que não chegaram muito a se 
concretizar, pela falta de recursos e capacidade de organização. Faltaram, provavelmente, empreendedores culturais periféricos como os que animam a cena paulista.

Meus interlocutores, em Recife, falam de uma realidade em que as clivagens de classe ainda sáo muito fortes: os coletivos que ocupam a cena da produção musical são formados por jovens universitários de classe média e divulgam, nos festivais independentes que organizam, produtos produzidos por eles mesmos; são pouquíssimas as bandas de periferia que conseguem ultrapassar o cerco, como os Devotos do Alto Zé do Pinho, e conquistar um espaço no mercado; mercado que, por sua vez, funciona na lógica do "pinçar" um dos muitos e exclui quem náo atinge um determinado patamar de "qualidade" técnica e artística.

Apesar do reconhecimento nacional e internacional que a música popular teve graças ao sucesso do movimento Mangue Beat, os grupos que fazem música popular ainda não têm apoio, as muitas bandas de jovens que fazem música nas periferias não têm acesso à formação musical. Um ou outro consegue se destacar, mas a grande maioria fica frustrada em seu sonho de viver de música ou de arte, experiência sem dúvida comum a muitos jovens em qualquer cidade do planeta.

A questão da organizaçáo de um movimento cultural autônomo, tanto em termos estéticos como políticos, não está em pauta. Para João Lin o que impede a organização coletiva é a forma como está organizado o mercado artístico: os produtores estão sempre à procura de algum talento a ser lançado no mercado. O que remete, para ele, à concepção difusa que considera a arte como um produto da criatividade e do "gênio" individual. Se, ao invés, concebemos a obra de arte como produto de um contexto social, histórico, geográfico e cultural, de uma coletividade, não faz sentido isolar um artista individualmente. Seria preciso, portanto, não apenas reivindicar um espaço, mas reformular as formas da produção e difusão.

O que está em jogo, em última instância, é a própria definição de um produto como arte. Quais produtos, e de que forma, chegam a ser consagrados como sendo arte? São os "curadores" que detêm o poder de legitimar algo como criação artística. Diz a esse respeito João Lin: 
é aquele esquema das artes visuais, das artes plásticas, das artes contemporâneas: você primeiro precisa ter um curador para dizer para você e para todo mundo que aquele trabalho que você faz é de boa qualidade, é um trabalho expressivo que merece ser respeitado como expressão artística de verdade. Mas a questão é: quem são os curadores? Os curadores são os caras que vêm da classe média, naturalmente, por quê? São os caras que estudaram. ${ }^{18}$

E que impóem, portanto, o padrão estético dominante. Assim como o padrão de divulgação, distribuição e fruição. Segue João Lin:

hoje o grafite precisa ser respeitado como arte e para isso no discurso deles tinha que estar na galeria, tinha que ser vendido caro. [...] tem um discurso que valoriza contanto que seja aquele cara que eu tire daquele contexto lá e diga 'olhe que coisa, esse é um representante daquilo e por ser representante ele é o melhor'. O cara que é o melhor é o cara que se destaca porque faz um trabalho que consegue agradar, ou estar dentro de um padrão que já está estabelecido, então tudo que for fora daquilo não vai ser tirado como destaque.

Nesse sentido, é interessante indagar se os artistas periféricos paulistas estariam questionando a forma como o mercado da arte está organizado, os padrôes de qualidade estéticos e a própria definição de arte.

\section{Arte, política e acionamento identitário}

O "fazer por nós mesmos" em vez de esperar que o poder público supre a falta de equipamentos e de serviços culturais que caracterizam os bairros de periferia; a ideia de resgate, a valorização da identidade territorial periférica; a afirmaçáo da autonomia, que se expressa também, às vezes, na recusa a se submeter à normatização implícita nos editais, a denúncia das condiçôes precárias dos serviços públicos da regiáo, o tema do desemprego sempre presente, do trabalho precário, da exploração, são conteúdos importantes da produção cultural periférica paulista. Expressóes como "o mundo é diferente da ponte para cá" (a ponte é a que cruza a marginal, na zona sul da cidade), ou "periferia é periferia em qualquer lugar", extraídas das letras dos Racionais Mc's, são paradigmáticas dessa postura política. Afirmar com orgulho de "ser da periferia" é uma experiência inédita. Nesse sentido, ser ou não da periferia é um dado fundamental que legitima a fala.

Questão central para os chamados "novos movimentos sociais", a questão identitária (no caso, territorial) deve ser interrogada e não naturalizada, ou

18 Entrevista concedida no dia 14/01/2011. 
colocada simplesmente como uma conquista que supera a (supostamente velha) questáo de classe. O geógrafo Rogério Hasbeart da Costa coloca, a esse respeito, uma questão que considero ponto de partida para a análise: "a pergunta não deve ser sobre a "verdade" da identidade, já que ela é sempre uma construção social, uma 'ilusão', mas sobre a eficácia: para que serve esse acionamento identitário, o que faz ao acionar/produzir uma identidade" (FROTSCHER; LAVERDI; VANDERLINDE, 2009, p. 170).

O acionamento identitário dos artistas periféricos paulistas opera uma afirmação política, enquanto reivindicação do pertencimento territorial a uma periferia simbolicamente unificada como alteridade, contraposta ao centro dominante; apela para o reconhecimento político de uma alteridade positivada. Representa, como eles dizem, um "ato de resistência". Quando esse acionamento identitário vira produto de mercado e é capturado pelo discurso oficial, como no contexto da celebração do talento artístico dos moradores das favelas (que seriam "naturalmente criativos") operada pelo discurso que projeta a imagem de uma cidade supostamente "integrada", vem à tona seus limites políticos.

Limites que, me parecem, dizem respeito à chamada "política de identidade" (FRASER, 2007). A antropóloga indiana Ananya Roy, citando Teresa Caldeira, capta bem os paradoxos dessas formas de agenciamento social: os jovens de periferia produzem, através de táticas culturais como o hip hop, uma crítica social poderosa; ao mesmo tempo, estabelecem uma distância não negociável entre pobres e ricos, centro e periferia, brancos e pretos, articulando uma posição de enclave (ROY, 2011, p. 232).

Nesse sentido, chamou minha atenção a fala de um jovem cineasta, Diego Bion, formado nos cursos das ONGs, que durante um debate afirmou com veemência: "eu não faço filme para ser mostrado em festivais de periferia. Eu faço filme, não de periferia" ${ }^{\prime 9}$. Evidentemente, a afirmação identitária pode virar uma etiqueta que limita as possibilidades de experimentaçáo, tanto em termos estéticos como de conteúdo. Cinema de periferia deve ser, forçadamente, socialmente engajado e neorrealista? Deve somente valorizar a periferia

19 Debate na Mostra "Angu à Francesa" organizado pelo coletivo Mate com Angú em Duque de Caxias, em dezembro 2010. Uma fala parecida é citada na dissertação de Maria José Motta Gouvêa numa entrevista com HB, um dos integrantes do coletivo (GOUVÊA, 2007, p. 70). 
e seus "valores", enquanto os cineastas de classe média podem fazer cinema experimental?

Por outro lado, além de valorizar sua autonomia e positivar seu pertencimento territorial, hoje os artistas periféricos de São Paulo estão também disputando um lugar no mercado. Aliás, é através do acionamento identitário que opera essa disputa. A inclusão (no e pelo mercado da arte) ocorre através da expressão da alteridade, territorial e política. Ou seja, os artistas periféricos fazem da sua localização periférica o valor agregado vendável no mercado, que, por sua vez, estava politicamente disponível a valorizar a produção periférica, tanto do ponto de vista da busca, sempre presente no mercado da arte, pela inovação, como do ponto de vista da descoberta-afirmação, toda política, de um lado "bom" da periferia. A artista Monica Nador, coordenadora do Jardim Miriam Arte Clube - JAMAC, no extremo sul de São Paulo, durante o Seminário "Estética da periferia" fez uma afirmação interessante: atividades desse tipo sempre aconteceram nas periferias, mas só agora conquistaram visibilidade na cidade, ultrapassando as fronteiras geográficas e simbólicas. Se assim for, cabe indagar: quais foram os fatores que provocaram essa visibilidade? Foi a capacidade de seus protagonistas, ou também uma conjuntura política favorável? Foi conquista ou concessáo? questionou Renildo Oliveira, do Movimento Culturald@s Guaianás, Cine Campinho e Arte Maloqueira da Zona Leste. No Rio, me parece, essa visibilidade serve a determinados interesses políticos, é parte da venda da "cidade maravilhosa", agora finalmente "pacificada" para acolher os grandes eventos esportivos mundiais (e os interesses econômicos que movimentam).

De qualquer forma, se a "cultura de periferia" virou um produto, uma marca que hoje está sendo exportada para outros estados do país e alguns produtores estão vendendo nos museus dos centros de poder, os artistas estão se beneficiando e, de certa forma, ajudando a produzir essa venda. A impressáo, ouvindo falar os artistas periféricos mais consagrados, durante o seminário de São Paulo, foi de que a transformação social virou também projeção e afirmação pessoal ${ }^{20}$.

A inserção no mercado, a relação com os governos e as fontes de financiamento são questôes sempre abertas e presentes nos debates entre os artistas

20 Agradeço Tiaraju d'Andrea por ter sugerido essa ideia, assim como pelas muitas e profícuas conversas sobre nossos temas de pesquisa. 
periféricos. Como vender sem fazer desaparecer o conflito, a carga de ruptura, a crítica à ordem vigente? Como negociar com políticos e empresários sem virar palanque eleitoral dos poderosos?

Os artistas periféricos estáo inventando para si outro lugar social, outro "itinerário de reconhecimento" (ROY, 2011), apelando para a superação do lugar subalterno através do reconhecimento do valor de sua arte. Mas como se dá esse reconhecimento? Quem está autorizado a operá-lo?

Em campo artístico, é a suposta qualidade, técnica e artística que consagra algum produto como sendo arte. Nesse sentido, os artistas periféricos paulistas se contrapóem a esse padráo dominante quando apelam para um reconhecimento territorial e político (o "ser da periferia") e náo estético. Todo mundo tem direito a se expressar, a pegar o microfone na frente de um público e declamar sua poesia, náo importa se "bela" ou "feia"; para todo mundo se exige silêncio (o "silêncio é uma prece" está escrito nos muros da Cooperifa, o sarau animado por Sérgio Vaz). Dessa forma, os moradores das periferias afirmam seu direito a fazer arte, sair da invisibilidade e da criminalização e se afirmar enquanto produtores de arte. A postura política se expressa no conteúdo veiculado nas letras, na vontade de se expressar e falar da própria condição de vida. Para alguns, sobretudo os mais jovens, é também a expressão da vontade de fugir ao destino: nem bandido nem mão de obra barata, e sim artistas.

Deixo para outros a tarefa de fazer uma análise mais cuidadosa dos valores estéticos dessa produção artística e indagar se e como questiona os padróes estéticos dominantes. Como bem mostrou Pierre Bourdieu, a hegemonia náo se expressa somente no plano econômico, e sim também no plano estético, artístico, cultural.

Mas, de que forma a própria ideia de "qualidade" é questionada? Para alguns, não se trata simplesmente de reivindicar e ocupar um espaço no mercado, aceitando as regras do jogo, e sim de mudar as regras. Para MC Leonardo, funkeiro carioca, nos bailes funks organizados na rua o que importa é o "estar junto" das pessoas, sem se colocar num "palco", físico e simbólico. Parecido ao que Joáo Lin coloca como característica do teatro de rua, em Recife:

acho que isso é influência de um modo de organizar o conhecimento: é preciso que existam os escolhidos, é preciso que existam as elites, porque isso mantém as relações de poder como elas são hoje, onde alguns têm merecimento e outros não, alguns podem ocupar esse 
espaço, merecem ocupar esse espaço e outros não. Não é só a grana, são outros valores também, é o saber mesmo. Eu acho que isso está de fato impregnado em todos os movimentos artísticos, mesmo os mais populares [...]. No teatro popular eu vejo assim, sempre se fez um discurso contrário a esse discurso da elite, independente de ser econômica - essa é a elite também da técnica, do saber. Para a gente que fazia teatro popular era muito isso, [...] o improviso, a capacidade de você estar junto coletivamente produzindo, isso é um valor do ator de teatro popular; então isso está na formação do ator. Na formação do ator de teatro popular é importante que ele tenha essa capacidade de interagir na ação teatral, de maneira que não necessariamente você tenha que ser um virtuoso tecnicamente. Mas se você tem isso, isso já é um valor dentro do teatro popular e não é só um discurso, porque às vezes pode parecer só um discurso. [...] na verdade não é, é por uma questão política mesmo, de entender que não são esses os valores que o teatro popular considera mais importantes na formação do ator, o do virtuoso, o da técnica. A gente entende técnica como outra coisa também. É técnica também a capacidade que você tem de se concentrar na rua enquanto está todo mundo falando, enquanto tem dez carros passando - e isso é técnica para o teatro de rua, essa capacidade de você se concentrar e ao mesmo tempo, se for o caso, você interagir com isso que está acontecendo fora, que é muito comum, chega um cara bêbado, entra no espetáculo, você não vai dar um tapa no bêbado, pelo contrário você vai incluí-lo lá. Ou um carro passou, teve um buzinaço, aí você entra naquele clima: já que você não pode falar o seu texto, você vai incluir aquilo. Então isso é qualidade técnica para o ator de teatro, não é só a capacidade de domínio do corpo, da voz e da interpretação.

\section{E continua:}

porque é inclusive aí que existe a possibilidade de se mudar esse conceito do que é bom e do que é belo, é a partir disso, desse estranhamento. Aí você começa a escutar algo que soa muito ruim, mas pode ser exatamente isso que soa muito ruim que tem um valor estético, que você não consegue perceber porque, obviamente, o que desafinou você não aceita. Acho que tem uma coisa parecida, para mim, no desenho. É muito forte isso, o desenho que é mal feito a gente tem uma repulsa por ele no primeiro momento, mas a partir do momento que você começa a lidar com ele, a interagir com ele, você começa a ver outros valores no desenho.

Cabe aqui recuperar um dos autores citados no início desse artigo. Para Jacques Rancière a arte é performática, é uma estética/política dos corpos que propóem uma outra repartição do visível, do pensável e do possível, uma outra "recomposição da paisagem do visível, da relação entre o fazer, o ser, o ver e o dizer" (RANCIÈRE, 2005, p. 69). Nesse sentido, os grupos que produzem arte e cultura nas periferias, seriam "coletivos de enunciação que repóem em questão a distribuição dos papéis, dos territórios e das linguagens - em resumo, desses sujeitos políticos que recolocam em causa a partilha já dada do 
sensível." (idem, p. 60). Os argumentos do autor podem ser considerados um "antídoto" contra a instrumentalização da cultura. A arte é política em si, não porque se coloca finalidades sociais ou políticas.

Da mesma forma, ele questiona com força o acionamento identitário como forma da política: "a subjetivação política se elabora não no âmbito de uma partilha de valores identitários, mas através do conflito, nas açóes e nas palavras que miram um bem público, na confrontação com outros sujeitos agentes e falantes" (MAGNI, 2007, p. 13).

As teóricas feministas vêm questionando, nos últimos anos, esse acionamento identitário; suas críticas são particularmente significativas justamente porque foram as feministas que colocaram em pauta a questáo da identidade no seio dos movimentos sociais. Nancy Fraser, filósofa e teórica feminista, assim formula sua crítica aguda às "políticas de identidade":

O modelo da identidade é profundamente problemático. Entendendo o não reconhecimento como um dano à identidade, ele enfatiza a estrutura psíquica em detrimento das instituições sociais e da interação social. Assim, ele arrisca substituir a mudança social por formas intrusas de engenharia da consciência. O modelo agrava esses riscos, ao posicionar a identidade de grupo como o objeto do reconhecimento. Enfatizando a elaboração e a manifestação de uma identidade coletiva autêntica, auto-afirmativa e autopoiética, ele submete os membros individuais a uma pressão moral a fim de se conformarem à cultura do grupo. Muitas vezes, o resultado é a imposição de uma identidade de grupo singular e drasticamente simplificada que nega a complexidade das vidas dos indivíduos, a multiplicidade de suas identificações e as interseções de suas várias filiações. Além disso, o modelo reifica a cultura. Ignorando as interações transculturais, ele trata as culturas como profundamente definidas, separadas e não interativas, como se fosse óbvio onde uma termina e a outra começa. Como resultado, ele tende a promover o separatismo e a enclausurar os grupos ao invés de fomentar interações entre eles. Ademais, ao negar a heterogeneidade interna, o modelo de identidade obscurece as disputas, dentro dos grupos sociais, por autoridade para representá-los, assim como por poder. Consequentemente, isso encobre o poder das facções dominantes e reforça a dominação interna. Então, em geral, o modelo da identidade aproxima-se muito facilmente de formas repressivas de comunitarismo. (FRASER, 2007, p. 106-107).

Sem dúvida, a problemática da política de identidade, o uso da arte e da cultura como instrumentos de gestão das populaçóes periféricas, a resistência operada via criação de empreendimentos culturais são pistas para ulteriores trabalhos analíticos. 
Do meu lado, sonho com um "somos todos Luther Blisset", personagem-fantoche que apareceu anos atrás na Itália e começou a assinar panfletos, intervençôes políticas e artísticas e até livros, obras de autores diferentes que nunca se conheceram, manifestação espontânea (cf. CANEVACCI, 2005, p. 100-107) que colocava em xeque a questâo autoral, lembrando o significado simbólico do passamontanha $a^{21}$ do Comandande Zapatista Marcos. Posicionamentos políticos que superam a questáo identitária e afirmam, mais uma vez mas em outras formas, o valor da força de rebeliáo do coletivo.

\section{Referências}

ABRAMO, H. W. Cenas juvenis: punk e darks no espetáculo urbano. São Paulo: Scritta, 1994.

ARANTES, O. Uma estratégia fatal: a cultura nas novas gestōes urbanas. In: Arantes O., Vainer, C., Maricato, E. A cidade do pensamento único: desmanchando consensos. Petrópolis: Vozes, 2000.

CANEVACCI, M. Culturas eXtremas: mutaçôes juvenis nos corpos das metrópoles. Rio de Janeiro: DP\&A, 2005.

DAGNINO, E. Os movimentos sociais e a emergência de uma nova noção de cidadania. In: Dagnino E. (Org.) Anos 90: política e sociedade no Brasil. Sáo Paulo: Brasiliense, 1994.

Sociedade civil, participação e cidadania: de que estamos falando? In: Daniel Mato

(Coord.) Políticas de ciudadanía y sociedad civil en tiempos de globalización. Caracas: FACES, Universidad Central de Venezuela, 2004.

FRASER, N. Reconhecimento sem ética? Lua Nova, São Paulo, n. 70, p. 101-138, 2007.

FROTSCHER; LAVERDI; VANDERLINDE. Entrevista com o geógrafo Rogério Haesbaert da Costa. Espaço Plural. Ano X. n. 20, p. 165-174, 2009.

GANNAM, G. G. A trama do sevirismo: os novos modelos de negócios da indústria cultural. São Paulo: ESP (Trabalho de Conclusão de Curso), 2008.

GOG. A rima denúncia. Sáo Paulo: Global, 2010.

GOUVÊA, M. J. M. Com a palavra Mate com Angu. Rio de Janeiro. Dissertação (Mestrado Profissionalizante em História, Bens Culturais e Projetos Sociais). Fundação Getúlio Vargas, 2007. HIKIJI, R. S. G. Sentidos da imagem na quebrada. In: Leonel, Juliana; Mendonça, R. (Org.) Audiovisual comunitário e educaçáo: Histórias, processos e produtos. Belo Horizonte: Autêntica Editora, 2010.

21 Boné utilizado pelos guerrilheiros zapatistas, que cobre o rosto. 
HOLANDA, H. B. A politica do Hip Hop nas favelas brasileiras. Disponível em: <http://www. inesc.org.br/biblioteca/textos/Le\%20monde\%20-\%20\%20Heloisa\%20Buarque.pdf>. Acesso em: 27 abr. 2012.

KOWARICK, L. A espoliaçáo urbana. Rio de Janeiro: Paz e Terra, 1980.

. As lutas sociais e a cidade. Rio de Janeiro: Paz e Terra, 1988.

LAZZARATO, M. La politica dell'evento. Soveria Mannelli: Rubettino, 2004.

MAGNI, B. Pensare la politica sotto il segno della divisione: l'itinerario eretico di Jacques Rancière (Introduzione). In: RANCIÈRE, J. Il disaccordo. Roma: Meltemi, 2007.

MOUFFE, C. Sul politico: democrazia e rappresentazione dei conflitti. Milano: Bruno Mondadori, 2007.

PAOLI, M. C. O mundo do indistinto: sobre gestáo, violência e política. In: OLIVEIRA, F. de; RIZEK, C. S. (Org.) A era da indeterminação. São Paulo: Boitempo, 2007.

PEÇANHA, E. Vozes marginais na literatura. Rio de Janeiro: Aeroplano, 2009.

RANCIÈRE, J. O desentendimento. São Paulo: Ed. 34, 1996.

A partilha do sensível: estética e política. São Paulo: Ed. 34, 2005.

REGUILLO, R. Emergencia de culturas juvenis: estrategias del desencanto. Bogotá: Grupo Editorial Norma, 2000.

ROY, A. Slumdog Cities: rethinking subaltern urbanism. International Journal of Urban and Regional Research; v. 35, n.2, p. 223-238, March 2011.

TOMMASI, L. Abordagens e práticas de trabalho com jovens: um olhar das organizaçôes não governamentais brasileiras. Jóvenes: Revista de Estudios sobre Juventud, México, a.9, n. 22, p.5879, enero-jun.,2005.

- Trabalho: necessidade, privilegio ou direito? Sociologia Ciência \& Vida [Especial Juventude Brasileira], São Paulo, a. 1, n. 2, p.24-35, 2007.

Nem bandidos nem trabalhadores baratos: trajetórias de jovens da periferia de Natal.

Dilemas: Revista de Estudos de Conflito e Controle social, Rio de Janeiro, v.5, n.1, p. 101-129, 2012.

VELAZCO, D. Intervençóes sociais ligadas à juventude e a produçáo da "Cidade Integrada" no Rio de Janeiro. Trabalho apresentado no Seminário Internacional Cidade e Alteridade, UFMG, 25-28 de setembro de 2012. 
VIANNA, H. Paradas do Sucesso Periférico. Sexta Feira, São Paulo, n. 8, p. 10-15, 2006.

YÚDICE, G. A conveniência da cultura: uso da cultura na era global. Belo Horizonte: Ed. UFMG, 2006.

\section{Cultures in urban peripheries: market, management dispositives and political action}

\section{Abstract}

The text presents the initial results of an exploratory research that aims to investigate cultural manifestations that occur in the periphery of three metropolitan regions Recife, Rio de Janeiro and São Paulo. The perception of the political action as empty-not making explicit a rupture in the existing order nor projecting new possible alternatives for the world- has motivated the search for different ways to express the conflict. Cultural practices and activities in urban peripheries are investigated, considering the political meaning that the involved subjects invest on them, looking for overcoming dicotomical visions, to investigate the ambiguous practices involving the art market and the social projects, the affirmation of territorial identity and its political limits, self management and entrepreneurship, the emprisoning discourse that wants to sustain the idea of the urban periphery's "pacification" and the affirmation of alterity, the personal projection and the transformation's possibilities.

Keywords: Periphery. Politics. Cultural movements. Periphery's art. Cultural production. 